\title{
Civilização e Barbárie
}

\section{Civilization and Barbarism}

Diogo da Silva Roiz'1

STAROBINSKI, J. As máscaras da civilização: ensaios. Tradução de Maria Lúcia Machado. São Paulo: Companhia das Letras, 2008.

\begin{abstract}
A palavra civilização pôde ser adotada tanto mais rapidamente quanto constituía um vocábulo sintético para um conceito preexistente, formulado anteriormente de maneira múltipla e variada: abrandamento dos costumes, educação dos espíritos, desenvolvimento da polidez, cultura das artes e das ciências, crescimento do comércio e da indústria, aquisição das comodidades materiais e do luxo. Para os indivíduos, os povos, a humanidade inteira, ela designa em primeiro lugar o processo que faz deles civilizados (termo preexistente), e depois o resultado cumulativo desse processo. É um conceito unificador (STAROBINSKI, 2008, p. 14).
\end{abstract}

Quando, em 1939, Norbert Elias lançou seu livro Oprocesso civilizador, o texto passaria despercebido pelo grande público, incluindo, aliás, parte significativa do especializado. Foi apenas nos anos de 1960 que o texto começaria a receber a atenção e o cuidado analítico merecido. Naquela ocasião, o autor já chamava atenção para a necessidade de apreendermos adequadamente as diferenças entre cultura (em sua acepção alemã) e civilização (em sua definição francesa), pois, elas sintetizavam o movimento do processo em andamento no Ocidente.

No Brasil, seu processo de recepção e apropriação também foi tardio. Os primeiros frutos de sua análise foram apresentados pela obra de
Renato Janine Ribeiro, em especial, A etiqueta no Antigo Regime (de 1983). Com A última razão dos reis (2002), esse autor novamente voltaria ao tema para abordar a fortuna crítica do Antigo Regime, bem como seu processo de dissolução no Ocidente. Almejando investigar a família real portuguesa no transcurso para sua colônia, em fins de 1807, aonde chegaria no ano seguinte, Jurandir Malerba (2000a) nos ofereceu um painel rico em pormenores acerca dos diferentes modos de tratamento entre europeus e nativos, civilização e barbárie, que acabaram por metamorfosear as condutas espirituais, culturais e morais de ambos. Em várias ocasiões, o mesmo autor procurou introduzir Elias para o leitor e o pesquisador brasileiro (MALERBA, 1996, MALERBA; CARDOSO, 2000b).

Jean Starobinski, ao contrário de Elias, não precisou esperar por décadas para receber o reconhecimento merecido. De igual modo, sua recepção no Brasil foi quase simultânea à publicação de suas obras na França. De 1789: os emblemas da razão a Invenção da liberdade, até Montesquieu, Montaigne em movimento e Jean-

\footnotetext{
${ }^{1}$ Doutorando em História pela UFPR, bolsista do CNPq. Mestre em História pela Unesp, Campus de Franca. Professor dos cursos de História e de Ciências Sociais da Universidade Estadual de Mato Grosso do Sul (UEMS), na Unidade de Amambaí. Email: diogosr@yahoo.com.br
} 
Jacques Rousseau: a transparência e o obstáculo, as idas e voltas sobre o Antigo e o Novo Regime na Europa, as representações da civilização e da barbárie, os traços de continuidades e rupturas entre os discursos, as transformações semânticas dos conceitos, e as mudanças socioculturais dos indivíduos foram tópicos examinados de maneira exímia, tal como um médico psiquiatra que aliou sua formação às habilidades literárias com o texto, poderia apresentar ao público.

Em As máscaras da civilização, novamente o autor se volta para a questão, delineando desde o itinerário do conceito, até seus diferentes usos sociais e intelectuais, nas penas de Montesquieu, Voltaire, Rousseau, e, em menor proporção, nos autores menos conhecidos do período. Além disso, interroga-se acerca dos resultados da doutrina clássica da civilidade, cuja produção da adulação era uma de suas conseqüências, dado que "tal como se elaborou nos cursos italianos do século XVI e nos salões parisienses do século XVII. Ele afirma em princípio que os laços recíprocos nos quais os homens são obrigados a entrar cotidianamente podem, em certas condições, não apenas ser purificados dos riscos da violência, mas tornarse fonte de prazer" (p. 57). Caso contrário, "para combater uma ilusão de civilidade que encobre a violência em vez de a reprimir", a sociedade deveria se reinventar, a "menos que se aceite a ilusão, dominando-a, exorcizando-a se possível, e que se consinta, entre pessoas devidamente prevenidas, em relações duvidosas - o que não ocorre sem fraqueza nem complacência, mas que é preferível a romper todos os laços" (p. 85).

Com esse roteiro, procurar-se-á analisar as Cartas persas, nas quais Montesquieu traceja um modelo de civilidade para a Europa, ao compará-la criticamente com o modelo oriental. Ao lado desta análise, encontrar-se-á uma interpretação sugestiva do Cândido de Voltaire, no qual verá que a "lei do fuzil de dois tiros [...] é a expressão de uma visão do mundo", na qual não " há bem sem mal, nem mal sem bem. Isso em proporções desiguais", pois, desse "movimento incessante, o conto voltairiano propõenos a imagem acelerada e caricatural, oscilando da natureza à cultura, do vício à virtude, do riso às lágrimas, do pessimismo ao otimismo - para nos deixar no duplo sentimento de confusão geral e da nitidez do detalhe discordante" (p. 160-161). Do estilo literário permeado por posições maniqueístas, as quais são encadeadas por dilemas satíricos, o autor nos revela um Rousseau preocupado com o mal presente na civilização ocidental, na qual o progresso se tornou sua meta final, e este em seu Discurso sobre as ciências e as artes visava a encontrar o remédio para essa enfermidade. Desse modo, "Rousseau nos sugere a suspensão do tempo: paraíso redescoberto da plenitude e da repetição que, no fim da história, pelo poder da arte, faz eco ao tempo não medido que obrigava sob sua sombra clara [...] a fusão natural do prazer e do desejo" (p. 230), pois, somente a volta ao passado genuíno poderia livrar a sociedade dos males causados pelo mundo moderno. Não seria por acaso, portanto, que de Rousseau o autor nos conduzisse de volta para as fábulas e mitologias dos séculos XVII e XVIII, em que, de um lado, "se estabelece no plano de todos os fatos de cultura [...] em que os motivos mitológicos são localizáveis", e, de outro, "é constituído pelo conjunto dos textos históricos, críticos, especulativos, que tentam elaborar um saber sobre os mitos, uma ciência dos mitos" ( $p$. 231). Por que sendo as fábulas "conjunto das noções aceitas quanto às divindades do paganismo" (cujo sentido moderno herdará novas acepções), foi a mitologia "isto é, o discurso erudito aplicado aos mitos - que destruiu o universo da fábula, mas deulhe, de maneira inesperada, razões de tomar novo impulso, sob uma forma ampliada e rejuvenescida" (p. 250). No entanto, "desse Mito irrealizado [das promessas da ciência moderna, como da religião no passado], todas as mitologias do mundo moderno são os sucedâneos e as miudezas" (p. 260).

Portanto, a obra destrincha os significados da civilização e da civilidade no mundo moderno, e avista seus desdobramentos nas transformações 
da cultura material, na revisão dos valores éticos e morais. Também se trata do conjunto de maneiras que regerem a sociabilidade dos indivíduos quando reunidos em grupos, seja ainda demonstrando como os letrados do período pensaram essas metamorfoses. Por isso este livro nos oferece um conjunto diversificado e bem amarrado de ensaios, para conhecermos as sutis tensões entre civilização e barbárie, civilidade e incivilidade, boa e má sociabilidade e vida social.

\section{Referências}

MALERBA, J. A corte no exílio: civilização e poder no Brasil às vésperas da Independência (18081821). São Paulo: Companhia das Letras, 2000a.

MALERBA, J.; CARDOSO, C. F. (Org.). Representações: contribuição a uma abordagem transdisciplinar. Campinas/SP: Papirus, 2000b.

- A velha história: teoria, método e historiografia. Campinas/SP: Papirus, 1996.

RIBEIRO, R. J. A última razão dos reis: ensaios sobre filosofia e política. São Paulo: Companhia das Letras, 2002.

. A etiqueta no Antigo Regime. São Paulo:

Brasiliense, 1983.

Recebido em: outubro de 2010

Aceito em: novembro de 2010 